$\begin{array}{llccccccr}\text { Volume } & 12, \quad \text { Nomor } & 1, \quad \text { Mei } & \text { 2020, } & \text { pp } & 109-122 & \text { Copyright } & \text { C } & 2017 \\ \text { Jurnal } & \text { Akuntansi, } & \text { Program } & \text { Studi } & \text { Akuntansi, } & \text { Fakultas } & \text { Ekonomi, } \\ \text { Universitas } & \text { Kristen } & \text { Maranatha. } & \text { ISSN } & 2085-8698 & \text { e-ISSN } & 2598-4977 .\end{array}$

http://journal.maranatha.edu

\title{
Peran Badan Permusyawaratan Desa dalam Pengelolaan Aset Desa
}

\author{
Mahenda Erarefra Putra \\ Fakultas Ekonomika dan Bisnis Program Studi Akuntansi-Universitas Kristen Satya Wacana \\ (Jl. Diponegoro No. 52-60, Salatiga, Jawa Tengah) \\ 232016239@student.uksw.edu

\section{Aprina Nugrahesthy Sulistya Hapsari} \\ Fakultas Ekonomika dan Bisnis Program Studi Akuntansi-Universitas Kristen Satya Wacana \\ (Jl. Diponegoro No. 52-60, Salatiga, Jawa Tengah) \\ esthy@staff.uksw.edu
}

\begin{abstract}
This study aims to describe the role of Badan Permusyawaratan Desa (BPD) in village assets management in Purworejo village, Purworejo Klampok sub-district, Banjarnegara Regency. Village assets are interesting to study because of the phenomena that occur indicate weaknesses in village assets management. On the other hand, village assets are an inseparable part of the government's efforts to increase village values and advance national development. This study uses a qualitative descriptive approach with in-depth interview method and observation as data collection methods. The participants in this study are members of BPD 2018-2024 and members of the community involved in village assets management. The results of this study indicated that the role of BPD in monitoring village assets management are apparent in all stages, especially in the stages of planning, procurement, transfers, administration, reporting and supervision. However, the role of the $B P D$ is constrained related to limited human resources, especially regarding each BPD members' educational background and their availability of time. In addition, the community itself still does not have a deep understanding of the role of BPD, so they feel that they have not been directly affected by the existence of BPD.
\end{abstract}

Keywords: Village Assets, BPD, Village Funds, and Monitoring

\begin{abstract}
Abstrak
Penelitian ini bertujuan untuk mendeskripsikan peran dari Badan Permusyawaratan Desa (BPD) dalam pengelolaan aset desa di Desa Purwareja, Kecamatan Purworejo Klampok, Kabupaten Banjarnegara. Aset desa menarik diteliti karena fenomena yang terjadi
\end{abstract}


menunjukkan adanya kelemahan dalam pengelolaan aset desa, sementara aset desa merupakan bagian yang tidak terpisahkan dari upaya pemerintah dalam meningkatkan nilai desa dan memajukan pembangunan nasional. Penelitian ini menggunakan pendekatan deskriptif kualitatif dengan teknik wawancara mendalam serta observasi sebagai teknik pengumpulan datanya. Narasumber dalam penelitian ini adalah BPD periode 2018-2024 dan warga masyarakat yang terlibat dalam pengelolaan aset desa. Hasil penelitian ini menunjukkan bahwa peran BPD dalam mengawasi pengelolaan aset desa nampak di seluruh tahapan, khususnya di tahap perencanaan, pengadaan, pemindahtanganan, penatausahaan, pelaporan dan pengawasan. Namun demikian peran BPD terkendala oleh adanya batasan terkait sumber daya manusia, khususnya terkait latar belakang pendidikan serta ketersediaan waktu dari masing-masing anggota BPD. Selain itu masyarakat sendiri masih belum memiliki pemahaman yang dalam terkait peran BPD, sehingga merasa belum secara langsung terdampak oleh adanya BPD.

\section{Kata Kunci: Aset Desa, BPD, Dana Desa, dan Pengawasan}

\section{Pendahuluan}

Revolusi industri 4.0 merangsang semua hal, bidang, lini dan organisasi untuk dapat melek teknologi. Demikan pula halnya dengan desa yang menjadi fokus perhatian pemerintah pusat dalam rangka pembangunan Indonesia dari pinggiran. Desa perlu mulai mempertimbangkan penggunaan teknologi untuk dapat melepaskan diri dari ketertinggalannya (Kementerian Desa Pembangunan Daerah Tertinggal dan Transmigrasi Republik Indonesia, 2018). Salah satu wujud dari hal tersebut adalah terkait dengan penggunaan sistem informasi dalam pengelolaan aset desa. Aset desa menarik untuk diteliti karena dalam pengelolaannya masih banyak terdapat kendala, sementara itu di sisi lain aset desa merupakan salah satu nilai yang dimiliki oleh desa dalam kaitannya untuk pengembangan desa menuju Indonesia yang lebih baik. Pengelolaan aset desa, sebagaimana diatur dalam Permendagri No. 1 tahun 2016, semestinya diharapkan dapat menciptakan nilai tambah bagi akuntabilitas dan transparansi laporan keuangan desa (Heriningsih, 2017).

Permasalahan pengelolaan aset desa sangat beragam, tetapi sebagian besar dikarenakan keterbatasan pengetahuan dan kemampuan sumber daya manusia yang mengelola aset. Kendala tersebut berawal dari pengelolaan aset daerah yang kemudian juga menjadi permasalahan di aras desa. Sebagai contoh adalah sikap tidak peduli terhadap pemeliharaan aset dapat dilihat dari catatan atas opini BPK terhadap keuangan Pemerintah Daerah yang hampir setiap tahunnya masih didominasi masalah pengelolaan barang milik negara. Bermasalahnya tata kelola aset di daerah ini dipengaruhi oleh beberapa hal, diantaranya adalah pemanfaatan aset oleh pihak lain yang tidak sesuai dengan prosedur atau adanya tukar menukar aset tanpa pemahaman administrasi pengelolaan aset (lan.go.id, 2016). Komisi Pemberantasan Korupsi pun menemukan banyak aset desa yang dikuasai oleh individu, baik itu berbentuk bangunan maupun tanah. Hal ini dikarenakan permasalahan aset yang masih dikuasai oeh pihak yang tidak memiliki hak atas aset baik itu masyarakat maupun pihak perorangan (Batampos.co.id, 2019). Permasalahan lainnya adalah para kepala desa yang tidak mencatat aset desa yang dibeli dengan menggunakan dana desa yang menyebabkan aset-aset yang dibiayai dari anggaran dana desa tersebut menjadi rawan 
untuk disalahgunakan (Simamora, 2019). Permasalahan aset desa cukup bervariasi, salah satunya kurangnya transparansi dan akuntabilitas dalam pengelolaannya, aset desa semestinya dapat didayagunakan untuk mewujudkan desa mandiri asal dapat dikelola dengan tepat. Pentingnya pengelolaan aset. Lebih jauh hal tersebut juga mulai menjadi fokus pemerintah untuk menggalakkan pengelolaan aset desa yang baik dengan menjadikan pengelolaan keuangan desa dan aset desa sebagai salah satu objek audit BPK (Haryadi, 2018).

Akuntabilitas dan transparansi merupakan hal yang penting dalam menciptakan tata kelola yang baik, tidak terkecuali untuk desa sebagai salah satu bentuk organisasi pemerintah (Purnomo \& Putri, 2018). Badan Permusyawaratan Desa sebagai wakil aspirasi masyarakat memiliki tugas untuk mengawasi kinerja kepala desa dalam menjalankan pemerintahan desa, salah satunya dalam hal pengelolaan aset desa agar dapat dipertanggungjawabkan kepada masyarakat.

Pemerintah desa adalah bagian yang tidak mungkin terpisah dalam pelaksanaan Negara Kesatuan Republik Indonesia (NKRI). Struktur kelembagaan terlebih pemerintahan desa yang langsung bersentuhan dengan masyarakat diharapkan untuk dapat menciptakan pemerintahan peka dan mampu menciptakan perubahan dan perkembangan ke arah yang lebih positif. Pemerintah desa merupakan pelaksana pemerintahan negara memiliki peran strategis sebagai ujung tombak untuk mencapai tujuan negara. Oleh karena itu, dalam penyelenggaraannya pemerintah desa dilengkapi dan dibantu dengan lembaga eksekutif dan lembaga legislatif dalam menjalankan tugas yang didalamnya dipegang oleh kepala desa dan perangkatnya sebagai lembaga eksekutif dan BPD sebagai lembaga legislatif (Romli \& Nurlia, 2017).

Undang-Undang Nomor 32 Tahun

2004 tentang Pemerintahan Desa menyatakan bahwa dalam pemerintahan daerah kabupaten/kota dibentuk pemerintahan desa yang terdiri dari Pemerintahan Desa dan BPD. Oleh karena itu, BPD merupakan unsur yang tidak dapat dipisahkan dari Pemerintah Desa dan anggota didalamnya dipilih dari dan oleh masyarakat desa setempat (Kusmanto, 2013). BPD merupakan lembaga yang memiliki fungsi pengawasan dalam kinerja pemerintah desa, tidak terkecuali dalam hal pengelolaan aset desa yang bersumber dari keuangan desa (keuangandesa.com, 2015). BPD berperan untuk dapat mengawal aset desa yang dimiliki oleh desa bisa bermanfaat secara optimal bagi kesejahteraan masyarakat dan bukan dinikmati hanya oleh segelintir orang saja.

Roza dan Arliman (2018) dalam penelitiannya menyatakan bahwa peranan BPD dalam melakukan pembangunan desa merupakan hal yang sangat vital karena mampu meningkatkan kualitas hidup dari masyarakat melalui tahap perencanaan, pelaksanaan dan juga pengawasan. Pelaksanaan pengawasan ini juga dilakukan untuk mendeteksi sejauh mana kebijakan kepala desa dan sejauh mana penyimpangan yang terjadi. Selanjutnya, Yuhandra (2016) menyatakan bawa fungsi pengawasan pelaksanaan pemerintah menjadi alasan pembentukan BPD, sehingga dapat mengurangi adanya penyelewengan atas kewenangan maupun keuangan desa dalam pelaksanaan pemerintahan desa. Mamahit (2017) menyatakan bahwa implementasi peran fungsi pengawasan yang dilakukan oleh BPD pada setiap tahap pengelolaan dana desa bervariasi yaitu maksimal dan kurang maksimal karena kurangnya partisipasi masyarakat.

Penelitian terdahulu terkait peran BPD lebih ditunjukkan dalam fungsi pengawasan terhadap pengelolaan keuangan desa seperti yang dilakukan oleh Ulfah Andriani \& Tatik Zulaika (2019) yang menunjukkan hasil bahwa perangkat desa di Desa Batu Raya I, dalam hal ini termasuk dengan BPD telah berperan dalam pengelolaan dana desa, meskipun hanya 
terbatas pada sekretaris desa dan kepala desa dikarenakan kurangnya pengetahuan dari perangkat lainnya tentang pengelolaan dana desa. Penelitian serupa dilakukan oleh (Akbar, 2017) yang memberikan hasil bahwa peran BPD dalam tahap perencanaan ADD di desa-desa wilayah Kecamatan Sadananya adalah menyampaikan aspirasi masyarakat dalam Musrenbangdes dan peran BPD dalam pengambilan keputusan pada tahap perencanaan pembangunan yang akan dilaksanakan, dimana pengambilan keputusan BPD dituangkan dalam bentuk Perdes yang sebelumnya telah disepakati bersama dengan Pemerintah Desa. Pada tahap pelaksanaan ADD, BPD berperan sebagai pengawas kegiatan serta berdialog dalam rapat evaluasi 3 bulanan untuk menyampaikan saran dan kritik yang berasal dari masyarakat. Sedangkan pada tahap pertanggungjawaban ADD, BPD mempunyai kewajiban untuk mengusung bahwa prinsip transparansi dalam pertanggungjawaban ADD harus diterapkan, selain itu BPD memastikan bahwa pelaksanaan ADD harus berjalan sesuai aturan yang berlaku.

Selain itu, penelitian lain menyebutkan bahwa masih terdapat desa yang belum memanfaatkan aset desa sesuai dengan peraturan perundang-undangan yang berlaku dan dibuktikan dengan mereka yang tidak memiliki peraturan desa mengenai pemanfaatan aset desa. Hal itu akhirnya menyebabkan suatu desa pada akhirnya gagal untuk mendapatkan hasil yang diinginkan yaitu meningkatkan pendapatan desa (Oksafiama, Suparnyo, \& Wicaksono, 2017).

Berdasarkan latar belakang di atas, maka penelitian bertujuan untuk mendeskripsikan peran BPD pada setiap tahapan pengelolaan aset desa, khususnya di Desa Purwareja, Kecamatan Purwareja Klampok, Kabupaten Banjarnegara. Pengelolaan aset desa merupakan tanggung jawab dari aparat desa, sementara itu tugas dari BPD adalah mengawasi kinerja kepala desa, sehingga peran pengawasan yang akan dideskripsikan dalam penelitian ini lebih pada melihat kinerja kepala desa dalam melakukan pengelolaan aset desa. Alasan pemilihan desa tersebut adalah dari wawancara awal dengan beberapa narasumber ditemukan minimnya pencatatan aset desa yang dilakukan oleh aparat desa. Hal inilah kemudian yang menjadi fokus dari penelitian ini untuk dapat lebih dalam melihat peran BPD dalam pengelolaan aset desa. Penelitian ini diharapkan dapat bermanfaat bagi: (1) BPD dan Pemerintah desa, yaitu dapat menjadi sarana evaluasi peran BPD dalam pengelolaan aset desa, untuk dapat lebih dioptimalkan demi kesejahteraan masyarakat; (2) Bagi Akademisi, yaitu dapat menambah referensi bagi penelitian berikutnya terkait akuntansi desa.

\section{Kerangka Teoritis}

\section{Pengelolaan Aset Desa}

Aset Desa menurut Peraturan Menteri Dalam Negeri Republik Indonesia Nomor 1 Tahun 2016 tentang Pengelolaan Aset Desa didefinisikan sebagai barang milik desa yang berasal dari kekayaan asli milik desa, dibeli atau diperoleh atas beban Anggaran Pendapatan dan Belanja Desa (APB Desa) atau perolehan Hak lainnya yang sah. Jenis aset desa adalah: (a) Kekayaan asli daerah; (b) Kekayaan milik desa yang dibeli atau diperoleh atas beban APBDesa; (c) Kekayaan desa yang diperoleh dari hibah dan sumbangan atau yang sejenis; (d) Kekayaan desa yang diperoleh sebagai pelaksanaan dari perjanjian/kontrak dan/atau diperoleh berdasarkan ketentuan peraturan undang-undang; (e) Hasil kerja sama desa; (f) Kekayaan desa yang berasal dari perolehan lain yang sah.

Pengelolaan aset desa merupakan rangkaian kegiatan mulai dari perencanaan, pengadaan, penggunaan, pemanfaatan, pengamanan, pemeliharaan, penghapusan, pemindahtanganan, penatausahaan, 
pelaporan, penilaian, pembinaan, pengawasan dan pengendalian aset desa. Perencanaan adalah tahapan kegiatan secara sistematis untuk merumuskan berbagai rincian kebutuhan barang milik desa. Pengadaan adalah kegiatan untuk melakukan pemenuhan kebutuhan barang dalam rangka penyelenggaraan pemerintahan desa. Penggunaan adalah kegiatan yang dilakukan oleh Pengguna Barang dalam menggunakan aset desa yang sesuai dengan tugas dan fungsi. Pemanfaatan adalah pendayagunaan aset desa secara tidak langsung dipergunakan dalam rangka penyelenggaraan tugas pemerintahan desa dan tidak mengubah status kepemilikan. Pengamanan adalah Proses, cara perbuatan mengamankan aset Desa dalam bentuk fisik, hukum, dan administratif. Pemeliharaan adalah kegiatan yang dilakukan agar semua aset desa selalu dalam keadaan baik dalam rangka penyelenggaraan pemerintahan desa.

Penghapusan adalah kegiatan menghapus/meniadakan aset desa dari buku data inventaris desa dengan keputusan kepala desa untuk membebaskan Pengelolaan Barang, Pengguna Barang, dan/ atau kuasa pengguna barang dari tanggung jawab administrasi dan fisik atas barang yang berada dalam pengguasaannya. Pemindahtanganan adalah pengalihan kepemilikan aset desa. Penatausahaan adalah rangkaian kegiatan yang dilakukan meliputi pembukuan, inventarisasi dan pelaporan aset desa sesuai dengan ketentuan yang berlaku. Pelaporan adalah penyajian keterangan berupa informasi terkait dengan keadaan objektif aset desa. Penilaian adalah suatu proses kegiatan pengukuran yang didasarkan pada data/fakta yang objektif dan relevan dengan menggunakan metode/teknis tertentu untuk memperoleh nilai aset desa. Pembinaan dan Pengawasan didefinisikan sebagai pihak-pihak terkait yang melakukan pembinaan dan pengawasan di luar pemerintahan desa dalam pelaksanaan pengelolaan aset desa.

\section{Badan Permusyawaratan Desa (BPD)}

Badan Permusyawaratan Desa (BPD) merupakan organisasi yang berfungsi sebagai badan yang menetapkan peraturan desa bersama Kepala Desa, menampung dan menyalurkan aspirasi masyarakat. Anggota BPD terdiri dari Ketua Rukun Warga, pemangku adat, golongan profesi, pemuka agama dan tokoh atau pemuka masyarakat lainnya berdasarkan keterwakilan wilayah yang ditetapkan dengan cara musyawarah dan mufakat (Punu, 2017). Undang-Undang Nomor 6 Tahun 2014 juga menjelaskan BPD mempunyai fungsi: a) membahas dan menyepakati Rancangan Peraturan Desa bersama Kepala Desa; b) menampung dan menyalurkan aspirasi masyarakat Desa; dan c) melakukan pengawasan kinerja Kepala Desa.

Pengawasan adalah suatu upaya yang sistematik untuk menerapkan kinerja standar pada pencapaian, untuk merancang sistem umpan balik informasi, untuk membandingkan kinerja aktual dengan standar yang telah ditentukan, dan untuk menerapkan telah terjadi suatu penyimpangan, serta untuk mengambil tindakan perbaikan yang diperlukan untuk menjamin bahwa semua sumber daya pemerintah telah digunakan secara efektif dan efisien mungkin guna untuk mencapai tujuan pemerintah (Sofiyanto, Mardani, \& Salim, 2017). Dalam laporan keterangan penyelenggaraan pemerintah desa yang memuat pelaksanaan peraturan desa digunakan oleh BPD dalam melaksanakan fungsi pengawasan kinerja Kepala Desa. Salah satu sumber perolehan aset desa adalah dana desa, di samping sumber dana lain yang masuk ke dalam komponen APBDes. Merujuk besarnya sumber pendanaan yang masuk dalam komponen APBDes tersebut, maka diperlukan kerjasama dengan masyarakat desa untuk mengawasi penggunaannya agar dipergunakan sebagaimana mestinya sehingga dapat meningkatkan kesejahteraan masyarakat desa, tidak terkecuali dalam hal 
pengelolaan aset desa. Pemerintah desa dituntut untuk menyelenggarakan pemerintahan secara, transparan dan akuntabel. BPD sebagai lembaga yang mempunyai fungsi pengawasan, diharapkan dapat menjalankan perannya secara efektif.

\section{Metode Penelitian}

\section{Jenis Penelitian dan Teknik Pengumpulan Data}

Penelitian ini merupakan penelitian dengan pendekatan deskriptif kualitatif yang mengambil objek penelitian di Desa Purwareja, Kecamatan Purwareja Klampok, Kabupaten Banjarnegara. Pemerolehan data dilakukan dengan menggunakan metoda wawancara mendalam dengan panduan pertanyaan yang nantinya dapat dikembangkan sampai dengan mendapatkan jawaban atas permasalahan penelitian. Adapun yang menjadi narasumber dalam penelitian ini adalah Wakil Ketua Badan Permusyawaratan Desa, Kepala Desa dan warga masyarakat sekitar yang mengetahui tentang pengelolaan aset desa.

\section{Teknik Analisis Data}

Data yang telah diperoleh dari hasil wawancara mendalam dan observasi kemudian dirangkum dalam transkrip wawancara untuk kemudian akan direduksi. Reduksi data bertujuan untuk memilih data yang relevan dalam menjawab permasalahan penelitian. Hasil dari reduksi data adalah data-data yang sudah lebih mengerucut pada identifikasi awal peran BPD dalam pengelolaan aset desa. Setelah dilakukan reduksi, tahapan analisis berikutnya adalah penyajian data dalam bentuk teks naratif. Artinya, dalam tahapan penyajian data ini identifikasi awal terkait peran BPD dalam pengelolaan aset desa dapat dijelaskan dengan lebih rinci dan mendalam. Tahapan analisis data terakhir adalah penarikan kesimpulan dan verifikasi. Dalam perumusan kesimpulan dan verifikasi, hasil penelitian sudah dapat menggambarkan peran BPD secara umum dan pelaksanaannya dalam pengelolaan aset desa. Bukti-bukti pendukung juga menjadi salah satu sarana untuk dapat menarik kesimpulan. Oleh sebab itu dalam penelitian ini juga menggunakan teknik triangulasi data untuk memperoleh keabsahan data. Triangulasi data ditunjukkan dengan melakukan konfirmasi dengan beberapa narasumber untuk pertanyaan yang sama, serta penguatan hasil dengan merujuk pada dokumendokumen pendukung.

\section{Hasil Penelitian dan Pembahasan}

\section{Gambaran Objek Penelitian}

BPD Desa Purwareja periode ini dibentuk pada tahun 2018, dengan masa bakti selama 6 tahun. Anggota BPD di desa Purwareja merupakan perwakilan dari 5 dusun yang ada di desa Purwareja, dengan setidaknya satu orang perwakilan dari tiap dusun. Komposisi dalam BPD disesuaikan dengan jumlah penduduk desa Purwareja yang sebanyak sekitar 10.000 jiwa dengan maksimal memiliki komposisi sejumlah 9 orang anggota BPD. Kepengurusan BPD Desa Purwareja saat ini adalah sebagai berikut Kepala BPD, Wakil Kepala BPD, dan Sekretaris BPD, serta 6 anggota BPD yang terbagi ke dalam dua bidang, yaitu bidang pemerintahan, bidang kemasyarakatan dan bidang pembangunan. BPD memiliki fungsi sebagai penjembatan dalam garis koordinasi antara masyarakat dan pemerintah desa.

\section{Peran BPD dalam Pengelolaan Aset Desa}

Tahapan awal dalam melakukan identifikasi terkait peran BPD adalah dengan memisahkan fungsi antara BPD dengan pemerintah desa. BPD dalam hal ini bertindak sebagai legislatif, sementara itu pemerintah desa bertindak sebagai eksekutif. Perbedaan fungsi ini tidak hanya tercakup dalam hal pengelolaan aset saja 
namun dalam bidang pemerintahan lainnya seperti contohnya pengelolaan keuangan, pemberdayaan masyarakat dan lain sebagainya. Hal tersebut sesuai dengan yang diungkapkan oleh pihak BPD Bidang Pemerintahan:

"Sementara ini sebagai mitra kerja aparat desa yang bertugas apabila terjadi sesuatu berkaitan dengan pemerintahan kita mengingatkan, kalau tentang pengelolaan aset desa memang tidak secara langsung."

Secara umum aset desa merupakan salah satu bagian penting yang menjadi fokus perhatian dari pemerintah desa dan BPD. Hal tersebut dikarenakan aset desa merupakan komponen yang berkaitan langsung dengan Pendapatan Asli Daerah (PAD) dan alokasi belanja daerah. Pernyataan yang mendukung hasil tersebut dikemukakan oleh Kepala Desa Purwareja

"Yang terkait dengan hal yang sifatnya strategis hukumnya wajib untuk dibahas bersama BPD, yang terkhusus membahas aset memang belum pernah, namun dalam RPJMDES dan RKPDES yang dibahas dalam musyawarah desa terdapat perencanaan pengadaan aset desa didalamnya. Aset desa kan selain menjadi PAD juga bisa sebagai alokasi dengan belanja modal, karena barang yang dibeli atau dibangun dengan masa pakai lebih dari setahun bisa dikategorikan sebagai aset."

Hal senada juga disampaikan oleh Wakil Ketua BPD:

"Harus dikontrol dengan baik karena pengelolaan aset desa akan sangat mempengaruhi $P A D$ dan APBDes"
Terkait dengan hal tersebut, maka sudah seharusnya peran BPD terlihat mulai dari tahapan perencanaan, karena apabila terjadi ketidaksesuaian atau penyimpangan aset dapat mempengaruhi komponen lain dalam APBDes. Proses perencanaan sendiri tidak dilakukan dengan satu kali proses rapat dan pengesahan saja, namun memerlukan beberapa tahap tertentu. Menurut Wakil Ketua BPD:

"Konsep perencanaan datang dari
pemerintah desa selaku eksekutif,
dan konsep ini diserahkan ke BPD
dan bisa dirapatkan dulu sendiri
oleh BPD, dan untuk penetapan
keputusan dilakukan bersama,
dalam hal ini (peran BPD) adalah
sebagai fungsi legalitas. BPD jelas
menanyakan dan melihat apakah
dengan pengadaan aset yang
direncanakan sesuai dengan
kebutuhan dasar masyarakat
wilayah terkait, dan BPD juga
bisa ketika merubah arahnya
pembangunan yang akan
dilaksanakan sehingga dapat
kembali lagi disesuaikan dengan
prioritas wilayah masing-masing.
Karena sebelum disahkan dan
masuk dalam APBDES dalam hal
ini RPJMDES dan RKPDES BPD
harus mengetahui perencanaan
dengan baik."

Sebelum menyerahkan konsep perencanaan di musyawarah desa kepada BPD, pemerintah desa selaku eksekutif melakukan perencanaan di tingkat paling rendah yaitu dusun, seperti penuturan dari Kepala Desa Purwareja.

"Karena disini ada rapat tingkat dusun, yang hadir tidak semua anggota BPD tapi BPD dapil sana, dengan kadus, kaur perencanaan, sekdes dan tokoh masyarakat sana untuk membahas perencanaan khusus wilayah sana. 
Ada daftar hadirnya njenengan (anda) bisa cek"

Hasil wawancara tersebut menunjukkan bahwa peran BPD di tahapan perencanaan adalah dengan ikut terlibat aktif dalam musyawarah dusun dan musyawarah desa, sehingga jika ditemukan adanya masalah terkait dengan perencanaan pengelolaan aset desa, pihak BPD dapat menjembatani antar kepentingan yang ada. Selain itu pihak BPD sebagai legislator berhak juga menanyakan atau juga membantu dalam proses pengarahan perencanaan pembangunan desa dalam satu periode ke depan agar optimalisasi perencanaan dapat terlaksana dengan baik dan juga sesuai dengan kebutuhan dasar masing-masing wilayah.

Pada tahap pengadaan, BPD memiliki peran tertentu, walau tidak secara spesifik terjun langsung di dalamnya. Hal ini berkaitan dengan pemisahan fungsi juga. Seperti yang dikatakan oleh Kepala Desa Purwareja:

"BPD kapasitasnya sebagai lembaga legislatif memang ikut merencanakan, yang melaksanakan adalah eksekutif, namun BPD tetap melakukan pengawasan, dalam artian ya perencanaan sudah matang dan disepakati selanjutnya diserahkan ke eksekutif. BPD fungsinya mengawasi artinya perencanaane dilakoni temenan apa ora (perencanaannya benar-benar dilaksanakan atau tidak)."

Senada dengan pernyataan dari pemerintah desa, Wakil Ketua BPD menyatakan:

"Tentunya, terkadang dalam proses tahapan pelaksanaan pembangunan, terkendala dalam tahap tertentu semisal proses pencairan dan BPD berperan dengan meminta keterangan mengapa belum terlaksana sehingga dapat saling mengetahui proses yang terjadi antara BPD dan pemerintah desa selaku eksekutor."

Peran BPD dalam pengadaan cenderung ke arah proses pelaksanaannya, dalam hal ini perannya adalah sebagai pengawas untuk memastikan proses pengadaan tersebut berjalan sebagaimana mestinya, sehingga potensi terjadinya kecurangan dapat diminimalisir, sebagai contoh BPD melakukan konfirmasi dengan pemerintah desa dengan meminta keterangan atau penjelasan dari pemerintah desa. Sementara itu untuk bagian pencarian vendor, penetapan upah pekerja dan sebagainya semua menjadi wewenang dari pemerintah desa.

Dalam tahapan lain yaitu penatausahaan dan pemindahtanganan tentunya BPD juga berperan besar. Ketika terjadi ketidaksesuaian dari penatausahaan dalam hal ini contohnya dalam hal inventarisasi tentunya mempengaruhi perencanaan APBDes. Sementara itu, dalam tahapan pemindahtanganan juga dapat mempengaruhi APBDes terutama dalam kejelasan kepemilikan aset desa. Dalam hal ini, peran BPD ditunjukkan dengan melakukan koordinasi dan konfirmasi kepada pihak pengelola aset desa.

Seperti pada pernyataan yang disampaikan oleh anggota BPD Bidang Pemerintahan:

"BPD sering menanyakan
kejelasan tentang aset desa,
apakah benar tercatat dan apakah
benar sesuai dengan keadaan di
lapangan dengan catatan yang
dimiliki desa? Disatu sisi juga
mengingatkan, dan desa juga
mencari tahu sebab ketidakjelasan
yang terjadi dan sudah ditemukan
sebabnya yang ternyata cukup
ribet (kompleks)."

" $B P D$ sering menanyakan apakah benar tercatat dan apaka apakah benar tercatat dan apakah benar sesuai dengan keadaan di dimiliki desa? Disatu sisi juga mengingatkan, dan desa juga mencari tahu sebab ketidakjelasan yang terjadi dan sudah ditemukan ribet (kompleks)." 
Pada tahapan terakhir yang menjadi fokus penelitian ini yaitu tahapan pelaporan sebagai bentuk pertanggungjawaban pengelolaan aset desa, BPD memiliki peran yang tidak jauh berbeda dengan tahapan sebelumnya yaitu peran pengawasan. Adapun yang menjadi keterbatasan dalam tahapan ini adalah belum adanya laporan secara khusus tentang pengelolaan aset desa. Meskipun demikian terkait dengan pemanfaatan aset desa dapat dilihat dalam laporan keuangan desa secara umum, sehingga peran BPD dalam hal ini juga terkait peran secara umum dalam pengawasan pengelolaan keuangan desa.

Peran BPD tercerminkan dari pernyataan BPD Bidang Pemerintahan:

"Sebenarnya mungkin dalam hal pelaporan dari pemerintah desa sendiri kurang tepat waktu, namun karena BPD hanya sebagai mitra jadi fungsi maksimal yang dapat dilakukan adalah memberikan rekomendasi."

Senada dengan pernyataan narasumber di atas, terkait keterlambatan pelaporan menjadi hal yang perlu dicermati oleh pemerintah desa karena dapat berkaitan dengan pelanggaran aturan dan dapat timbul sanksi, berikut penuturan Wakil Ketua BPD:

"BPD mengingatkan apakah hasil pelaksanaan sudah dilaporkan atau belum, karena aparat desa terkait dengan pelaporan tidak bisa dengan seenaknya sendiri, karena apabila ada keterlambatan pelaporan dapat menghambat proses tahap pencairan program lainnya. Kalau yang namanya keterlambatan bisa diperbaiki namun kealphaan dalam pembuatan laporan itu suatu bentuk kesalahan dan ada punishmentnya sendiri ada sanksi

hukum dan diatur dalam
peraturan. Kita mengingatkan
terus, dan ketika ada
penyimpangan akan keluar
rekomendasi dari BPD yang
didapat dari hasil investigasi,
selanjutnya akan ada sikap dari
pemerintah desa, jika tidak dapat
diselesaikan oleh aparat desa akan
dilanjutkan ke kecamatan dan
apabila belum selesai juga
nantinya akan dilanjutkan lagi ke
inspektorat dan itu bukan ranah
BPD lagi apabila sudah sampaike
inspektorat."

Menjadi hal yang sangat penting untuk dicermati karena pelaporan yang baik tentunya dapat membawa pengaruh yang baik bagi program kerja yang lainnya, dan itu tidak hanya berkaitan dengan aset desa saja namun dalam hal lainnya secara umum. BPD tentunya sudah melakukan perannya dengan baik untuk memberi dorongan dan peringatan bagi pemerintah desa, namun untuk praktik pelaksanaannya tetap kembali kepada pemerintah desa sebagai eksekutif apakah dapat diselesaikan dengan baik atau tidak, karena jika tidak dapat diselesaikan akan menjadi hal yang dapat dicurigai oleh inspektorat dan hal tersebut yang berusaha untuk dihindari oleh BPD.

\section{Kendala Implementasi Peran BPD}

Selain peran yang sudah dijelaskan sebelumnya, BPD juga memiliki peran untuk mendorong pemerintah desa mengelola aset desa dengan baik dan transparan. Sejauh ini BPD merasa bahwa pemerintah desa sudah melakukan hal tersebut, namun masyarakat desa justru tidak memiliki rasa ingin tahu terkait dengan pengelolaan aset desa.

Hal tersebut sesuai dengan pernyataan yang disampaikan oleh Kepala Desa Purwareja.

"Untuk aset transparansinya ada, tapi untuk spesifik aset belum 
dilaksanakan, masih menyatu dengan APBDES. Khusus pengelolaan aset belum sepenuh hati karena masih berusaha memahami Permendagri no.1 tahun 2016, dan itu sekarang sejak UU no 6 tahun 2014 pemerintah desa wajib hukumnya menginformasikan kepada masyarakat dengan imenampilkan infografis dan di desa Purwareja ditampilkan dalam baliho di depan balai desa, yang artinya sudah dilaksanakan, dan infografis tidak hanya satu namun di tiap dusun ada."

Hasil tersebut juga didukung dengan pernyataan Wakil Ketua BPD yang menyatakan transparansi pengelolaan desa melalui infografis desa.

"BPD justru berperan sebagai corong perwakilan masyarakat desa dalam kelembagaan. Terdapat infografis tentang perencanaan desa, yang kedepannya akan diperluas lagi (cakupan wilayahnya). Infografis itu isinya adalah sumber-sumber pendapatan dari alokasi dana desa, alokasi anggaran desa, dan sumber lainnya yang sah dan juga di dalamnya disampaikan progress pelaksanaan pembangunan. Program ini belum maksimal karena masyarakat belum membacanya, namun diupayakan kedepannya akan semakin diperluas, dengan harapan minat masyarakat membaca akan meningkat."

Bagi masyarakat sendiri kinerja dari pemerintah desa maupun BPD hanya dapat dilihat dari hasilnya saja, sebagai contoh ketika terdapat kegiatan pengaspalan jalan baru dapat dilihat hasilnya pada lokasinya seperti apa. Masyarakat yang tidak mengetahui secara terperinci kegiatan pemerintahan maupun kelembagaan yang dilakukan oleh aparat desa dan BPD, hanya dapat melihat koordinasi antara keduanya melalui cara berkomunikasi dan berhubungan antar satu sama lain.

Berikut penuturan masyarakat mengenai peran BPD dan kinerja secara umum BPD dengan pemerintah desa:

"BPD desa dengan aparat desa terlihat sudah cukup baik dalam hubungan kerja maupun non kerja, namun dengan masyarakat dirasa kurang, karena masih banyak ketidakpahaman masyarakat mengenai BPD. Cukup tau lah seputar BPD. BPD pengawasannya sudah baik, aset desa dirasa akan terjaga dengan baik, namun yang berkaitan dengan kinerja dan seluk-beluk aktivitas dirasa kurang paham terutama aktivitas BPD yang diluar wilayah saya. Diharapkan lebih bersinergi dalam kerja, lebih mengutamakan hak masyarakat. Apa yang sekiranya harus disampaikan ke masyarakat dan berkaitan dengan kepentingan masyarakat. BPD dan pemerintah desa diharapkan lebih gencar bersosialisasi kepada masyarakat umum, karena masyarakat merasa 'hanya sebatas memandang' dan tidak mengetahui lebih dalam."

Permasalahan lain yang muncul dalam pelaksanaan peran BPD terdapat dalam internal BPD. Hal tersebut disampaikan oleh Wakil Ketua BPD, BPD Bidang Pemerintahan dan Kepala Desa Purwareja. "Ya tetap ada kendala itu karna
komposisi BPD sementara ini
sekian banyak memiliki profesi
artinya selaku ASN dari sisi waktu
mereka terbatas karena harus
bertugas sebagai ASN disatu sisi 
memiliki tugas sebagai BPD, namun demikian bisa disikapi dengan mengadakan pertemuan di malam hari. Selain itu berkenaan dengan SDM itu memang memiliki latar belakang yang berbeda, ada yang memang relevan dengan studi pemerintahan, sebagian memiliki latar belakang sarjana pendidikan, itu yang kadang kadang masih perlu butuh waktu untuk adaptasi. Teman teman yang belum paham ini sambil berjalan berusaha belajar dan memahami regulasi yang berlaku." (Wakil Ketua BPD)

"Masalah sudah dari periode sebelumnya karena saya juga dari periode sebelumnya. Ada namun tidak signifikan yaitu waktu yang terbatas untuk melakukan rapat ataupun berkoordinasi, tentunya setelah periodisasi baru dimulai akan melaksanakn peningkatan kerjasama antara BPD dan aparat desa." (BPD Bidang Pemerintahan)

"Secara umum kendala tidak begitu nampak, sebagian besar anggota BPD punya aktivitas yang dapat dikatakan waktu kosong untuk bisa bareng-bareng berkoordinasi ya kita harus menanyakan kesediaan waktu dari $B P D$, dan sekarang praktiknya dilaksanakan malam, jadi kita mengalah karena sudah ada solusi dengan diadakan rapat di malam hari karena sejauh ini belum pernah diadakan rapat siang yang berbenturan dengan aktivitas anggota BPD agar bisa lebih maksimal." (Kepala Desa Purwareja)

Permasalahan yang dihadapi oleh BPD lebih berpusat pada internal BPD itu sendiri yaitu keterbatasan SDM yang tersedia dan juga waktu yang relatif tidak banyak. Anggota BPD yang terpilih sebagian besar memang sudah berpendidikan strata satu, namun tidak dalam fokus studi mengenai pemerintahan, sehingga tidak semua yang memiliki gelar sarjana dapat memahami dengan baik regulasi dan proses administrasi yang berlaku. Selain itu terdapat masalah terkait keterbatasan waktu, karena sebagian besar anggota BPD masih aktif bekerja sebagai ASN (Aparatur Sipil Negara) sehingga waktu yang tersedia untuk bertugas sebagai BPD terbatas. Permasalahan tersebut sudah disiasati dengan menggunakan waktu luang yang tersedia namun juga riskan apabila ada hal mendadak yang sifatnya insidental tidak dapat segera diselesaikan.

Meskipun memiliki beberapa kendala internal, peran BPD dalam pengelolaan aset desa tidak dapat dilepaskan dalam unsur pemerintahan karena sangat penting seperti yang disampaikan oleh Kepala Desa Purwareja dan Wakil Ketua BPD sebagai berikut:

"Menurut saya sangat penting, karena tanpa pengawasan dari $B P D$ itu potensi penyimpangan menjadi lebih terbuka, minimal kalau kita selalu diawasi itu kan misalkan kok ada sedikit potensi akan penyimpangan segera bisa diatasi, ya dalam segala hal baik itu pengadaan untuk barang atau aset juga yang lainnya terutama keuangan juga, karena keuangan dan aset dua hal yang merupakan satu kesatuan juga. Intinya pengawasan sangat penting." (Kepala Desa Purwareja)

"Secara jujur saat ini sudah menuju era digital, sementara aparat desa yang generasi lama belum maтри menyesuaikan, diharapkan mampu menguasai era digital karena memang tuntutan, 
dan maтри memahami sistem administrasi dengan IT, untuk mempermudah dan mempersempit kemungkinan penyimpangan. BPD sudah mengusahakan dengan sudah mengadakan pertemuan dengan aparat desa, tidak sekedar mendorong tetapi memotivasi mereka untuk mengikuti tuntutan dalam artian tuntutan kerjaan sekarang, dan juga mengawasi kinerja mereka apakah sudah sesuai dengan tuntutan."(Wakil Ketua BPD)

Hasil wawancara menunjukkan bahwa pengelolaan aset desa yang tidak sesuai dengan peraturan perundangan yang berlaku akan sangat mungkin terjadi, namun semestinya BPD yang bertindak sebagai wakil dari masyarakat sekaligus sebagai pengemban tugas untuk mengawasi kinerja kepala desa dapat menjadi salah satu garda pertahanan untuk selalu mengingatkan aparat desa agar lebih optimal dalam mengelola aset desa. BPD Desa perlu memahami aturan yang berlaku, dalam hal ini yaitu Permendagri Nomor 1 Tahun 2016 agar meminimalkan pelanggaran hukum yang dilakukan oleh aparatur Desa karena ketidakpahaman pihak terkait pada aturan tersebut.

\section{Simpulan dan Saran}

\section{Simpulan}

Penelitian ini memberikan hasil bahwa pengawasan BPD terhadap kinerja khususnya dalam pengelolaan aset desa ditunjukkan melalui tahapan pengelolaan aset desa. Peran ini pengawasan ini tidak ditunjukkan secara langsung, karena sebagaimana telah dijelaskan sebelumnya, bahwa yang menjadi tugas dari BPD adalah mengawasi kinerja kepala desa, salah satunya ditunjukkan melalui pengelolaan aset desa. Dalam hal tersebut, peran-peran yang dilakukan oleh BPD adalah berperan aktif mengkritisi, mengkoordinasi dan mengkonfrontasi jika ditemukan ada hal-hal yang dirasa perlu diarahkan. BPD memiliki keinginan dan harapan supaya pengelolaan aset desa dapat lebih transparan dan mengacu pada peraturan yang berlaku. Meski demikian dalam pengimplementasian perannya, BPD masih memiliki beberapa kendala, khususnya terkait dengan sumber daya manusia yang memiliki latar belakang pendidikan yang berbeda dan keterbatasan waktu yang dimiliki oleh anggota BPD untuk lebih fokus dalam melaksanakan tugasnya. Namun, hal tersebut tidak lantas menyurutkan misi dari BPD untuk terus membina dan mengemban tugas dalam hal pengawasannya, salah satunya melalui teknologi informasi yang berkembang saat ini. Tujuan akhirnya adalah supaya BPD sebagai wakil dari masyarakat juga memperoleh hasil pengelolaan aset desa yang transparan dan akuntabel.

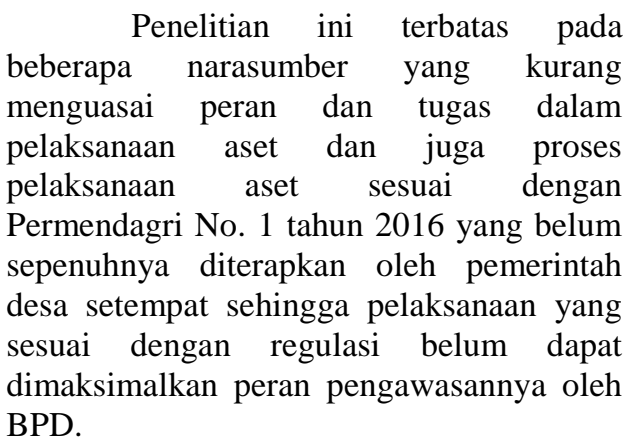

\section{Saran}

Saran yang dapat diberikan untuk penelitian berikutnya adalah melakukan analisis terhadap praktik pengelolaan aset desa, khususnya dari sisi akuntabilitas ataupun transparan. Selain itu terkait dengan peran BPD dapat dibuat penelitian yang menunjukkan peran BPD dalam membantu pemerintah desa untuk menciptakan pengelolaan keuangan desa melalui penerapan prinsip-prinsip tata kelola yang baik. 


\section{Daftar Pustaka}

Akbar, D. S. (2017). Peran Badan Permusyawaratan Desa (BPD) Dalam Mewujudkan Akuntabilitas Alokasi Dana Desa (ADD) (Penelitian Pada Desa-Desa di Wilayah Kecamatan Sadananya). Jurnal Edukasi (Ekonomi, Pendidikan dan Akuntansi). 5(2), 109-120.

Batampos.co.id. (2019). Aset Daerah Dikuasai Individu.

Haryadi, D. (2018). Pengelolaan Keuangan dan Aset Desa, Jadi Objek Audit BPK. Retrieved from https://www.ayobandung.com/read/20 18/10/31/39968/pengelolaankeuangan-dan-aset-desa-jadi-objekaudit-bpk

Heriningsih, S. (2017). Best Practices Pengelolaan Aset Desa Di Desa Jagalan Kabupaten Bantul. Jurnal Ekonomi Dan Bisnis, 20(6), 21-31.

Kementerian Dalam Negeri. (2016) Permendagri Nomor 1 Tahun 2016.

Kementerian Desa Pembangunan Daerah Tertinggal dan Transmigrasi Republik Indonesia. (2018). Kemendes PDTT dorong desa membangun dengan terapkan teknologi 4.0.

Keuangandesa.com. (2015). Dasar Hukum Pengawasan Dana Desa oleh BPD.

Kusmanto, H. (2013). Peran Badan Permusyawaratan Daerah dalam meningkatkan partisipasi politik masyarakat. Jurnal Ilmu Pemerintahan Dan Sosial Politik, 1(1), 39-47.

Lan.go.id. (2016). Pengelolaan Aset Masih menjadi Masalah.

Mamahit, S. (2017). Peranan Badan Permusyawaratan Desa dalam pelaksanaan fungsi pengawasan pada pengelolaan alokasi dana desa (Studi di Desa Lobu Dua Kecamatan Touluaan Kabupaten Minahasa Tenggara). 1-14.

Oksafiama, L., Suparnyo, \& Wicaksono, A. (2017). Pemanfaatan aset desa dalam upaya meningkatkan pendapatan desa. Jurnal Suara Keadilan, 18(2), 66-78.

Pemerintah Republik Indonesia. (2014). Undang-Undang Republik Indonesia nomor 6 tahun 2014 tentang Desa.

Peraturan Pemerintah Indonesia. (2004). Undang-Undang No 32 Tahun 2004 Tentang Pemerintah Daerah. 249.

Punu, E. J. (2017). Fungsi Badan Permusyawaratan Desa (BPD) Dalam Pengawasan Penyelenggaraan Pemerintahan Di Desa Wiau - Lapi Kecamatan Tareran Kabupaten Minahasa Selatan. Jurnal Ilmu Pemerintahan, 1-20.

Purnomo, B. S., \& Putri, C. (2018). Akuntabilitas, Transparansi, Pengawasan dan Kinerja Anggaran Berkonsep Value For Money. Jurnal Riset Akuntansi dan Keuangan, 6(3), 467-480.

Romli, O., \& Nurlia, E. (2017). Lemahnya Badan Permusyawaratan Desa (BPD) dalam melaksanakan fungsi pemerintahan desa (Studi Desa Tegalwangi Kecamatan Menes Kabupaten Pandeglang). Jurnal Ilmu Pemerintahan, 3(1), 36-54.

Roza, D., \& Arliman, L. (2018). Peran Badan Permusyawaratan Desa di Dalam Pembangunan Desa dan Pengawasan Keuangan Desa. PADJADJARAN Jurnal Ilmu Hukum (Journal of Law), 4(3), 606-624. https://doi.org/10.22304/pjih.v4n3.a1 0

Simamora, A. (2019). Kasat Reskrim Polres Bintan Ingatkan Kepala Desa Catat Aset Desa Agar Tidak Terjerat Tindak Pidana.

Sofiyanto, M., Mardani, R. M., \& Salim, A. (2017). Pengelolaan dana desa dalam upaya meningkatkan pembangunan di Desa Banyuates Kabupaten Sampang. Jurnal Riset Manajemen, 6(4). 
Jurnal Akuntansi a Volume 12 Nomor 1, Mei 2020: 109-122

Ulfah Andriani, \& Tatik Zulaika. (2019). Peran Perangkat Desa Dalam Akuntabilitas Pengelolaan Dana Desa. Jurnal Akademi Akuntansi, 2(2), 119-144.

Yuhandra, E. (2016). Kewenangan BPD (Badan Permusyawaratan Desa) dalam menjalankan fungsi legislasi (Sebuah Telaah Sosiologis Proses Pembentukan Perdes di Desa Karamatwangi Kec. Garawangi Kab. Kuningan). UNIFIKASI : Jurnal Ilmu Hukum, 3(2), 61-76. https://doi.org/10.25134/unifikasi.v3i 2.410 